センサの柔軟な選択・設置を可能とする 移動ロボットのプラグアンドプレイ型自己位置推定法*

\author{
菅 沼 直 樹*1, 林 雄 一*2

\section{Plug and Play Type Ego-Motion Estimator of Mobile Robot for Flexible Sensor Selection and Installation}

\author{
Naoki SUGANUMA*3 and Yuichi HAYASHI \\ ${ }^{* 3}$ Institute of Science and Engineering, Kanazawa University, \\ Kakuma-machi, Kanazawa-shi, Ishikawa, 920-1192 Japan
}

\begin{abstract}
In this paper, for an ego-motion estimating problem of mobile robot, we propose plug and play type ego-motion estimator that user can freely select sensor type and flexibly install the sensor. In this algorithm, each sensor is dealt as a sensor unit that has computing equipment, and each sensor unit estimate ego-motion and the sensor parameter. Moreover, sensor units are connected via network, ego-motion estimate of each unit are exchanged each other. Then the exchanged information is fused by Covariance Intersection method, which is one of a decentralized estimator. By this, this algorithm can estimate ego-motion not affected by number of sensors and sensor type. Furthermore, user can flexibly install the sensors by this algorithm because sensor parameters are estimated in each unit and compensated information are exchanged each other. In addition to this high flexibility, an experimental results denotes that our method estimate ego-motion with adequate accuracy.
\end{abstract}

Key Words: Plug and Play, Sensor Fusion, Decentralized Estimator, Covariance Intersection, Moving Robot, Ego-Motion, Filter

\section{1. 緒 言}

近年, 多種多様の自律移動ロボットか潤発され，幅広い 分野での活躍が期待されている．例えば，人では作業が困 難な災害現場などの何険な環境で作業を行う危険作業口ボ ット (1) や，人の代わりに作業を行う事により人の生活を便 利にする自律邹除ロボット ${ }^{(2)}$, 人間をサポートする知能車 椅子 ${ }^{(3)}$ などが挙げられる.このようなロボットが自律的も しくは半自律的に移動し，作業を行うためには様々な技術 が必要となる. その中でもロボットの自己位置姿勢を推定 することは重要な共通基般技術のうちの一つである.

従来, 移動ロボットの自己位置推定䦔顛に対して, 複数 のセン州情報を統合する事によりロバストから精度よく自 己位置を求める多くの手法が提案されている. 例えば, GPS，ジャイロ，オドメトリをカルマンフィルタに基づき 統合し自動車の自己位置を推定する手法 ${ }^{(4)}$ や, 既知の位置 に設置されたランドマークを移動ロボット上のカメラで計 測し，オドメトリと統合する手法 ${ }^{(5)}$ などがある. 一方，多 種多様のロボットの自己位置推定に適切なセンサは，口ボ ットの種類，環境などに依存し，様々なものが考えられる. このため精度, 確害性，経済性等を考慮し，専門的知識を

* 原稿受付 2009 年 9 月 3 日.

*1 正員, 金沢大学理工研究域 (丞920-1192 全沢市角間町).

*2 金沢大学大学院自然科学研究科.

E-mail : suganuma@ @uma.ms.t.kanazawa-u.ac.jp
有する設計者がセンサの選択・設置を行うと同時に，これら のセンサに適した推定アルゴリズムを個々に設計する必要 があった. また，センサ設置位置のキャリブレーション校 正も必要であった このためユーザが使用環境に応じて柔 軟にセンサを選択し，柔軟にレイアウトを変更することが 極めて困難であるという問題があった，そこで本研究では 次世代型のセンサフュージョンアルゴリズムとして，ユー ザによるセンサの柔軟な選択・設置を可能とする移動ロボ ットのプラグアンドプレイ型自己位置推定法を提案する.

\section{2. 中央集中型位置推定法}

本章では，従来の一般的な自己位置推定手法である中央 集中型垃置推定法について述へ，その問題点を指摘する.

2.1 移動口ボット 図1に本研究で使用した移動口 ボットを示寸．本ロボットは我々が開発した左右独立駆動 (Power Wheeled Steering : PWS)の輪型移動ロボットであ り，最大 $20[\mathrm{~m} / \mathrm{s}]$ 速度で走行が可能である. 本ロボットの 左右两輪には光学式エンコーダが設置してあり，100[Hz]の 周期で左右再輪の進行距離を計測することができる.また 本移動ロボットには, RTK-GPS 受信機(Novatel 社製 OEM4 G2-RT20)か設置されており，上空方開けている場合約 $20 \mathrm{~cm}$ 程度の精度でロボットの絶対位置を計測することができる. また同受信機加らは，GPS 搬送波信号のドップラー効果に より，ロボットの進行方向を計測することが可能となって 


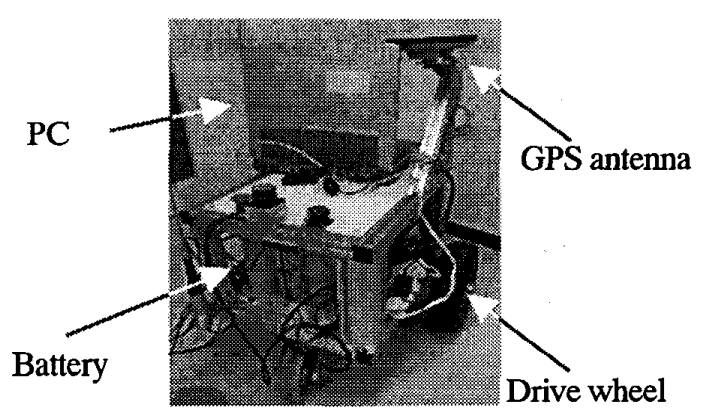

Fig.1 Overview of mobile robot

いる. ただし図2に示すように RTK-GPS アンテナはロボ ットの左右両輪の中心位置(以降簡単にロボット中心と述 ベる)からずれた位置に設置されている.

2.2 拡張カルマンフィルタを用いた位置推定 次に, 前節で述べた移動ロボットに搭載したセンサの情報を統合 し，移動ロボットの位置姿勢を推定することを考える.

いま, 移動ロボットが二次元平面内を移動すると仮定す る. また図 2 に示すように，移動ロボットの位置姿勢を $\mathrm{x}=[x y \theta]^{\mathrm{T}}$ で表し, 左右两輪のパルス変化辩(パルス速度)を $\mathbf{u}=\left[u_{L} u_{R}\right]^{\mathrm{T}}$ とする. このとき微小時間 $\tau$ 内において, 移動口 ボットは

$$
\begin{aligned}
\mathbf{x}_{t} & =\mathbf{f}\left(\mathbf{x}_{t-1}, \mathbf{u}_{t-1}\right) \\
& =\left[\begin{array}{c}
x_{t-1}+V_{t-1} \tau \cos \left(\gamma_{t-1} \tau\right) \\
y_{t-1}+V_{t-1} \tau \sin \left(\gamma_{t-1} \tau\right) \\
\theta_{t-1}+\gamma_{t-1} \tau
\end{array}\right]
\end{aligned}
$$

の運動を行うと近時できる. ただし，Vおよび $\gamma$ はロボッ 卜の進行方向速度, 回転角速度を示し,

$$
\begin{gathered}
V=\left(\mu_{R} u_{R}+\mu_{L} u_{L}\right) / 2 \\
\gamma=\left(\mu_{R} u_{R}-\mu_{L} u_{L}\right) / T
\end{gathered}
$$

で得られる.ただし $\mu_{\text {上 }} \mu_{R}$ はそれぞれ左右輪のパルス保数パ ルス数に対寸る進行距離の比)であり, $T$ はトレッドである. いま式(1)で示す運動モデルに，車輪速計測呮差に起因する 誤差 $\mathbf{w}=\left[w_{L} w_{R}\right]^{\mathrm{T}}$ が加わると仮定すれば，誤差を考慮した システムモデルは

$$
\mathbf{x}_{t}=\mathbf{f}\left(\mathbf{x}_{t-1}, \mathbf{u}_{t-1}+\mathbf{w}_{t-1}\right)
$$

と記述できる. このときシステム誤差 w が, 平均値 $\mathbf{0}$, 共 分散行列 $\mathbf{Q}$ なる正規分布に従うとすると, 移動ロボットの 位置姿勢の予測推定值 $\hat{\mathbf{x}}_{t / t-1}$ および予㵋骂差共分散行列 $\hat{\mathbf{P}}_{t / l-1}$ は

$$
\begin{aligned}
& \hat{\mathbf{x}}_{t / t-1}=\mathbf{f}\left(\hat{\mathbf{x}}_{t-1 / t-1}, \mathbf{u}_{t-1}\right) \\
& \hat{\mathbf{P}}_{t / t-1}=\mathbf{F}_{t-1} \hat{\mathbf{P}}_{t-1 / t-1} \mathbf{F}_{t-1}^{T}+\mathbf{G}_{t-1} \mathbf{Q}_{t-1} \mathbf{G}_{t-1}^{T}
\end{aligned}
$$

と近似できる．ただし， $\mathbf{F}=\partial \mathbf{f} / \partial \mathbf{x}, \mathbf{G}=\partial \mathbf{f} / \partial \mathbf{w}$ である.

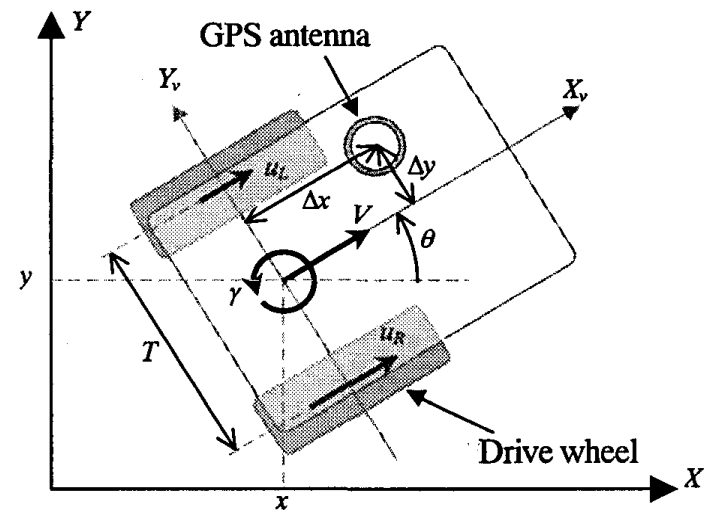

Fig.2 Geometry of mobile robot

一方，移動ロボットには RTK-GPS アンテナが設置され ており，絶対位置 $z^{1}=\left[z^{x} z^{y}\right]^{\top}$ を観測できる. また，本移動口 ボットで用いた RTK-GPS 受信機では，GPS 搬送波信号の ドップラー効果により進行方向ベクトル $z^{2}=z^{\theta}$ が観測でき る.これらの観測值に対して，それぞれ $v^{1}=\left[v^{x} v^{y}\right]^{\top}$ および $v^{2}=v^{\theta}$ の観測㝇差が加わると仮定すれば，観測王デルは

$$
\begin{aligned}
\mathbf{z}_{t}^{1} & =\mathbf{h}^{1}\left(\mathbf{x}_{t}\right)+\mathbf{v}_{t}^{1} \\
& =\left[\begin{array}{l}
x_{t}+\Delta x \cos \theta-\Delta y \sin \theta+v^{x} \\
y_{t}+\Delta x \sin \theta+\Delta y \cos \theta+v^{y}
\end{array}\right] \\
z_{t}^{2} & =\mathbf{h}^{2}\left(\mathbf{x}_{t}\right)+v_{t}^{2}=\theta_{t}+v^{\theta}
\end{aligned}
$$

と記述できる. ただし $\Delta x, \Delta y$ は，ロボット中心と GPS ア ンテナの設置位置との間のずれである (図2)。このとき観 㵋竞差 $\mathbf{v}^{i}$ が，平均值 $\mathbf{0}$ ，共分散行列 $\mathbf{R}^{i}$ なる正規分布に従う とすると, 拡張カルマンフィルタのフレームワークにより， 移動ロボットの位置姿勢推定值 $\hat{\mathbf{x}}_{t / t}$ およひ㩆差共分散行列 $\hat{\mathbf{P}}_{t / t}$ は

$$
\begin{aligned}
& \hat{\mathbf{x}}_{t / t}=\hat{\mathbf{x}}_{t / t-1}+\mathbf{K}_{t}\left\{\mathbf{z}_{t}-\mathbf{h}^{i}\left(\hat{\mathbf{x}}_{t / t-1}\right)\right\} \\
& \hat{\mathbf{P}}_{t / t}=\hat{\mathbf{P}}_{t / t-1}-\mathbf{K}_{t}^{i} \mathbf{S}_{t}^{i}\left(\mathbf{K}_{t}^{i}\right)^{T}
\end{aligned}
$$

として求めることができる. ただし，行列 $\mathbf{S} ， \mathbf{K}$ はそれぞ れ観測予貺照差共分散行列およびカルマンゲインであり，

$$
\begin{aligned}
& \mathbf{S}_{t}^{i}=\mathbf{H}^{i} \hat{\mathbf{P}}_{t / t-1}\left(\mathbf{H}^{i}\right)^{r}+\mathbf{R}_{t}^{i} \\
& \mathbf{K}_{t}^{i}=\hat{\mathbf{P}}_{t / t-1}\left(\mathbf{H}^{i}\right)^{T}\left(\mathbf{S}_{t}^{i}\right)^{-1}
\end{aligned}
$$

で計算される. ただし, $\mathbf{H}^{i}=\partial \mathbf{h}^{i} / \partial \mathbf{x}$ である.

具体的な統合手順としては，一定周期で䡛輪速度を計測 し, 式(4)，(5)を用いて移動ロボットの位置姿勢を予測する。 そして各観測值が得られたら，各観測值について順次式(8) および(9)を適用することで, 各センサ情報を統合した推定 值を得ることができる.

2 -3 センサパラメータと自己位置の同時推定 前節 
で述べた方法では，センサパラメータが既知であると仮定 して推定を行った. しかし，センサの柔軟な設置を可能と するためにはセンサパラメータを自動的に推定できること が望ましい：この方法として，末知パラメータを状態変数 の一部として定義し，自己位置と同時にセンサパラメータ を求める適応カルマンフィルタがある.

いま, 移動ロボットの観測值に含まれるパラメータは GPS アンデ位置 $\xi^{\mathrm{pm}}=[\Delta x \Delta y]^{\mathrm{T}}$ である.これらのパラメー 夕は，センサの設置位置に関するものであるから時間的に 変化しない.このことから，観測パラメータと移動ロボッ トのシステムモデルの拡大系を構成すれば，式(3)のシステ ムモデルは

$$
\left[\begin{array}{c}
\mathbf{x}_{t} \\
\xi_{t}^{p r m}
\end{array}\right]=\left[\begin{array}{c}
\mathbf{f}\left(\mathbf{x}_{t-1}, \mathbf{u}_{t-1}+\mathbf{w}_{t-1}\right) \\
\xi_{t-1}^{p r m}
\end{array}\right]
$$

と記述し直すことができる．従って，前節における式(3)を 上式に䛃み替え，式(のたおける $\Delta x, \Delta y$ が状態変数となるこ とに注意して式(4)〜(11)を再設計することで, 昖張カルマン フィルタのフレームワークとしてロボットの自己位置とセ ンサパラメータを同時に推定することができる.

一方，上述の手法でセンサパラメータを同時推定する場 合，センサパラメータを状態変数の一部として組み入れる ため, 使用するセンサの種類·数を変更するためにはフィル 夕全体を再設計する必要が生じる．このため，あらゆる状 況を想定し，接続するセンサの種類·数を予め設計しておか ない限り，ニーザが自由にセンサを変更することができな いという問題がある. この問題に対し，分散型の位置推定 手法に基づき情報統合を行う手法も提案されている ${ }^{(6)}$ が, センサパラメータが存在する場合の自動校正手法について は未検討であった。

そこで本研究では、ユーザによるセンサの柔軟な選択を 可能とし，自己位置及びセンサパラメータを同時推定する ことでユーザによる柔軟なセンサ設置を可能とする Plug and Play 型位置推定法を提案する.

\section{Plug and Play 型位置推定法}

3-1 Plug and Play 型自己位置推定法(概要 図 3(b) に本論文て提案寸る Plug and Play (PnP) 型自己位置推定法 の概略を示す. 図3(a)に示すようなセン州情報を1つの演 算器に集約して情報統合を行う中央集中型統合手法とは異 なり, PnP 型位置推定法は分散型の情報統合手法に基つい ている. また各センサは，センサ単体としてではなく演算 器を有するセンサユニットとして取り扱われる. 移動ロボ ットおよび各センサユニットはネットワークを介して接続 され，移動ロボットから各センサユニットには移動ロボッ トの運動情報(オドメトリ)が伝详される. また各センサユニ
ットでは，ユニットに接続されたセン州報とロボットか ら送信された運動情報を統合して，ユニット毎に位置姿勢 の推定值を生成する. そして各センサニニットはネットワ 一クを介してお互いの位置姿勢推定值を送受信し，情報統 合を行うことで，センサの数に依存せず全てのセンサ情報 を加味した位置姿勢推定值を生成することができる.一方， 各センサ固有のセンサパラメータはセンサュニット内で自 動的に推定される.このため, センサパラメータを補正し た後の位置姿勢推定値が各ユニット間で送受信されるため, センサパラメータに依存しない汎用的な情報統合手法とな っている. またユニット間で送受信する情報は，センサの 種類に依存せず常に位置姿勢推定值とすることで, 各セン サの種類に依存しない情報統合手法となっている.

このようにPnP型位置推定法では，接続されるセンサの 数・種類・センサ固有のパラメータに依存せす情報統合が 可能であるため, ユ一ザによるセンサの柔軟な選択・設置を 可能とすることができる．以下，具体的な手法について述 ベる.

3 - 2 センサユニット内の情報統合＼cjkstart各センサユニッ ト内では，基本的に前節で述べた適灾カルマンフィルタに 基づい, 移動ロボットの位置姿勢およびセンサパラメー タの同時推定を行う. なお本研究では，2 章で述べた RTK-GPS の位置観測值およひ管勢観測值が異なる原理で 計測されたものであり，観則值間の誤差に相関性がないこ

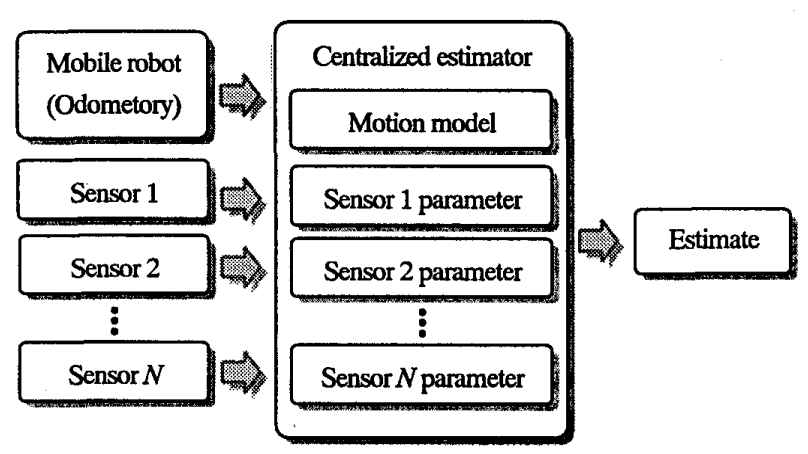

(a) Centralized type estimator

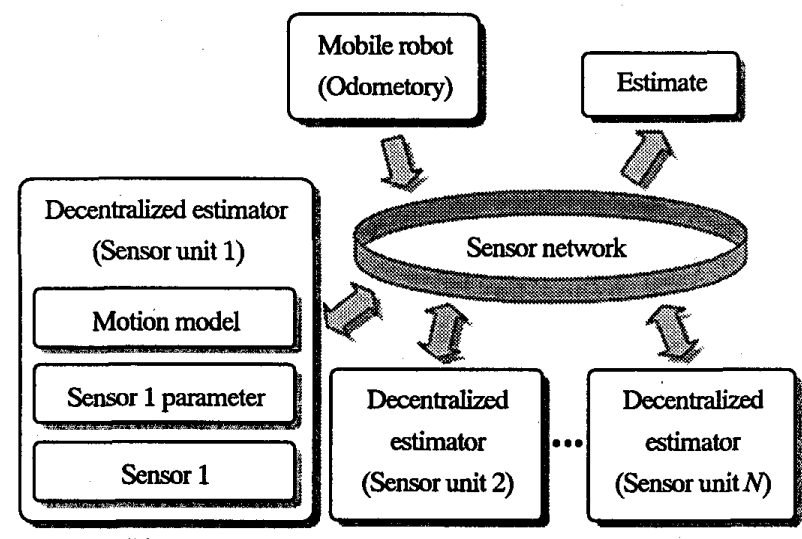

(b) Plug and play (decentralized) type estimator

Fig. 3 Overview of sensor fusion method 
とから，便宜的にこれらを別々のセンサであると仮定し， それぞれを異なるセンサユニットとして取り扱う。

まず，GPS'位置観則徝をセン州情報として取り扱うユニ ット(以後 GPS 位置ニニットと呼ふ)について考える.2 章で も述べたように，GPS 位置ユニットではセンサパラメータ として GPS アンテナ設置位置が存在している。このため, 移動ロボットの位置姿勢 $\mathbf{x}=[x y \theta]^{\mathrm{T}}$ およびGPS アンテナ設

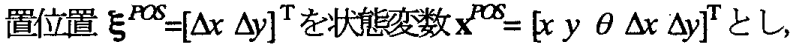
移動ロボットから送信された運動情報 $\mathbf{u}=\left[u_{L} u_{R}\right]^{\mathrm{T}}$ に基づき， システムモデルを構築すると，

$$
\begin{aligned}
& \mathbf{x}_{t}^{P O S}=\mathbf{f}^{P O S}\left(\mathbf{x}_{t-1}^{P O S}, \mathbf{u}_{t-1}+\mathbf{w}_{t-1}\right) \\
& {\left[\begin{array}{c}
\mathbf{x}_{t-1} \\
\xi_{t-1}^{P O S}
\end{array}\right]=\left[\begin{array}{c}
\mathbf{f}\left(\mathbf{x}_{t-1}, \mathbf{u}_{t-1}+\mathbf{w}_{t-1}\right) \\
\xi_{t-1}^{P O S}
\end{array}\right] }
\end{aligned}
$$

となる.また，観測モデルは

$$
\begin{aligned}
\mathbf{z}_{t}^{P O S} & =\mathbf{h}^{P O S}\left(\mathbf{x}_{t}^{P O S}\right)+\mathbf{v}_{t}^{P O S} \\
& =\left[\begin{array}{l}
x_{t}+\Delta x \cos \theta-\Delta y \sin \theta+v^{x} \\
y_{t}+\Delta x \sin \theta+\Delta y \cos \theta+v^{y}
\end{array}\right]
\end{aligned}
$$

と表される.

次に，GPS 姿勢観測值をセン州情報として取り扱うユニ ット(以後 GPS 姿勢ニニットと呼ふ)について考える. GPS 姿勢観則值にはセンサパラメータか存在しない:このため, GPS 姿勢ユニットの状態变数は $\mathbf{x}^{A L T}=\mathbf{x}=[x y \theta]^{\mathrm{T}}$ となる.こ のため，システムモデルおよひ観測モデルは 2 章と同一の 形となり

$$
\begin{aligned}
& \mathbf{x}_{t}^{A L T}=\mathbf{f}\left(\mathbf{x}_{t}^{A L T}, \mathbf{u}_{t-1}+\mathbf{w}_{t-1}\right) \\
& z_{t}^{A L T}=h^{A L T}\left(\mathbf{x}_{t}^{A L T}\right)+v_{t}^{A L T}=\theta_{t}+v^{\theta}
\end{aligned}
$$

\section{と記述できる。}

これらの式を基に，各ユニット毎に拡張カルマンフィル タを用いてロボットの位置姿勢およびセンサパラメータの 同時推定を行う.

3 -3 センサユニット間の情報統合 次に，各センサ ユニットで推定した移動ロボットの位置姿勢情報を, ネッ トワークを介してユニット間で情報統合する力法について 述べる.

本論文で提案するP PnP型位置推定法では，図3(b)に示寸 ように，センサネットワークを介してセンサュニット間で 推定情報を送受信し合うことで情報統合を行う。いま，あ る1つのユニット $i$ に着目して情報の流れを考える.このと き, $\mathrm{PnP}$ 型位置推定法では, 時刻 $t$ においてユニット $i$ で推 定した情報が他ユニットに送出され，他ユニットの情報と 統合される. このため時刻 $t+1$ 以降では, 他ユニットから 送出された情報には時刻 $t$ においてユニット $i$ が持っていた
誤差に起因する誤差が少なからず含まれていることになる. 従って，ユニット間で統合する情報には，お互いか沪有す る誤差に相関関係が存在しており，これを無視して統合す ると正しい惟定值を得ることができない：そこで本研究で は，統合する情報間に相関関係が存在する場合でも情報統 合を行うことが可能な Covariance Intersection (C) 法 ${ }^{(7)}$ を用 いてセンサユニット間の情報統合を行うこととした．以下 にCI 法の概略を述べる.

いま，同一の次元を持 $\boldsymbol{n}$ 個の情報 $\mathrm{x}_{1}, \mathrm{x}_{2} \cdots, \mathrm{x}_{n}$ と，そ れに対匛した誤差共分散行列 $\mathbf{P}_{1}, \mathbf{P}_{2}, \cdots, \mathbf{P}_{n}$ 落得られたとす る.このとき， C法ではこれらの情報を統合した推定值 $\hat{\mathbf{x}}$ およひ演吴差共分散行列 $\hat{\mathbf{P}}$ を次式により求める.

$$
\hat{\mathbf{P}}^{-1}=\omega_{1} \mathbf{P}_{1}^{-1}+\omega_{2} \mathbf{P}_{2}^{-1}+\cdots+\omega_{n} \mathbf{P}_{n}^{-1}
$$

$$
\hat{\mathbf{P}}^{-1} \hat{\mathbf{X}}=\omega_{1} \mathbf{P}_{1}^{-1} \mathbf{x}_{1}+\omega_{2} \mathbf{P}_{2}^{-1} \mathbf{x}_{2}+\cdots+\omega_{n} \mathbf{P}_{n}^{-1} \mathbf{x}_{n}
$$

ただし， $\omega_{i}(i=1,2, \cdots, n)$ は重み倸数であり, $0<\omega_{i}<1$ かわ $\omega_{1}+\omega_{2}+\cdots+\omega_{n}=1$ となる值をとり, $\operatorname{det}[\hat{\mathbf{P}}]$ を最小とするよ うに選ぶ。

図4は，C法の情報統合フレームワークに基づきユニッ 卜間の情報統合を行う PnP 型位置推定法の情報統合の概略 を示したものである. 各センサユニットは，一定の閒隔で センサネットワークから運動聙埌(オドメトリ)を受信し，シ ステムモデルに基づき予測推定值および予測㗊差共分散行 列を計算する(Time update). そして, 各ユニットに接続した セン州情報から拡張カルマンフィルタに基づき一時的な状 態推定值及乙詻差共分散行列を計算し(Partial estimate), セン サネットワークに送信する. 次に，他ユニットから送信さ れた Partial estimate を受信し，式(17)および(18)に基づき自ユ ニットおよび他ユニットの情報を統合する(Inter-unit fusion). 最後に，各ユニットに接続したセンサ情報から拡張カルマ ンフィルタに基づき最終的な状態推定值及乙站差共分散行 列を計算する(Final estimate).これにより，全てのセンサ情 報を加味ししつつ, 各センサユニットが自律分散的に位置 姿勢を推定することが可能となる.

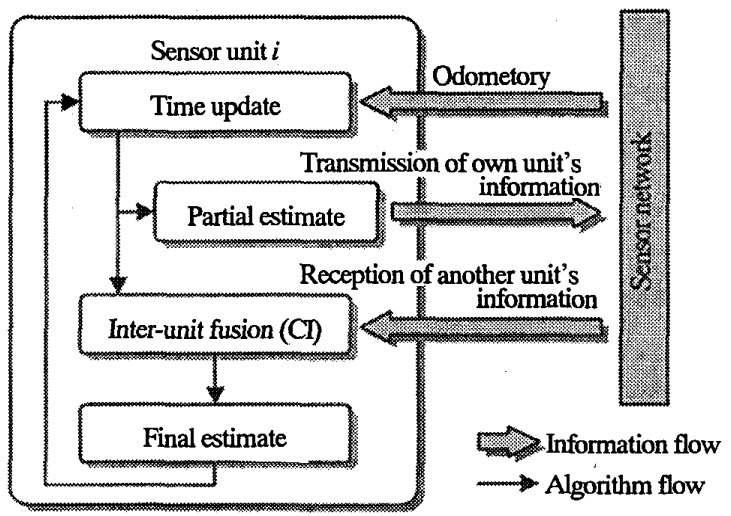

Fig.4 Overview of PnP estimator 
$\mathbf{x}^{P O S}=\left[\begin{array}{c}x \\ y \\ y x \\ \Delta y\end{array}\right] \quad \mathbf{P}^{P O S}=\left[\begin{array}{llllll}p_{11} & p_{12} & p_{13} & p_{14} & p_{15} \\ p_{21} & p_{22} & p_{23} & p_{24} & p_{25} \\ p_{31} & p_{32} & p_{33} & p_{34} & p_{35} \\ \hdashline p_{41} & p_{42} & p_{43} & p_{44} & p_{45} \\ p_{51} & p_{52} & p_{53} & p_{54} & p_{55}\end{array}\right]$

(a) Reduction of information

(In case of GPS position unit)

${ }_{P O S} \mathbf{x}^{A L T}=\left[\begin{array}{c}\bar{x} \\ y \\ \theta \\ 0 \\ 0\end{array}\right]\left({ }_{P O S} \mathbf{P}^{A L T}\right)^{-1}=\left[\begin{array}{ccc:cc}p_{11}^{-1} & p_{12}^{-1} & p_{13}^{-1} & 0 & 0 \\ p_{21}^{-1} & p_{22}^{-1} & p_{23}^{-1} & 0 & 0 \\ p_{31}^{-1} & p_{32}^{-1} & p_{43}^{-1} & 0 & 0 \\ \hdashline 0 & 0 & 0 & 0 & 0 \\ 0 & 0 & 0 & 0 & 0\end{array}\right]$

(b) Expansion of information

(In case of information from GPS altitude unit)

Fig.5 Reduction and expansion of information

3.1 節で述べたように, PnP 型位置推定法では任意の種類 のセンサユニットを接続可能とするため, 各ユニット間で 送受信する情報はどんなセンサユニットであったとしても 位置姿勢情報としている. しかし実際に忙，各センサュニ ットの推定值にはセンサパラメータが存在するため, セン サネットワークへ情報を送信する際はセンサパラメータを 除いた位置姿勢情報を送信する必要がある(情報の縮小). 例 えば本研究で用いている GPS 位置ユニットの場合, 図 5(a) に示すようにユニット内の推定値は 5 次元である.このう ち，位置知勢に関する推定值およびそれに対応する誤差共 分散行列の部分行列のみをネットワーク八送信する.

一方，センサネットワークから受信する情報にはセンサ パラメータが含まれていない：このため, 自ユニットのセ ンサパラメータを含む推定值と，他ユニットから送信され る位置姿勢推定值を CI 法に基づき統合するためには，他工 ニットから送信された情報を自ユニットのセンサパラメー 夕を含む次元に合わせる必要がある(情報の拡大). 例として GPS位置ニニットがセンサネットワークからGPS姿勢二ニ ットの情報を受信した場合について考えれば, 受信した GPS姿勢ュニットの推定值にはGPS位置ニニットのセンサ パラメータが含まれていないため, 図 5(b)に示すようにセ ンサパラメータに該当する部分を便宜的に 0 で拡張する.

一方誤差共分散については，受信した誤差共分散行列の逆 行列を計算し，センサパラメータに該当する要素は 0 で拡 張する.これは，誤差共分散行列のセンサパラメータに対 応する要素をのとすることに相当しており, 0 で拡張したセ ンサパラメータに対応する推定值には，なんら情報が存在 していないことを意味する. このように縮小・抁張された他
Table 1 Specification of mobile robot

\begin{tabular}{c|c|c}
\hline \multicolumn{2}{c|}{ Tread $T$} & $0.48[\mathrm{~m}]$ \\
\hline \multirow{2}{*}{$\begin{array}{c}\text { GPS antenna } \\
\text { offset }\end{array}$} & $\Delta x$ & $-0.040[\mathrm{~m}]$ \\
\cline { 2 - 3 } $\begin{array}{c}\text { Pulse } \\
\text { coefficient }\end{array}$ & $\Delta y$ & $0.135[\mathrm{~m}]$ \\
\cline { 2 - 3 } & Left tire $\mu_{\tau}$ & $8.03 \times 10^{-5}[\mathrm{~m} /$ pulse $]$ \\
\hline \multirow{3}{*}{$\begin{array}{c}\text { Standard } \\
\text { deviation }\end{array}$} & Right tire $\mu_{R}$ & $8.06 \times 10^{-5}[\mathrm{~m} / \mathrm{pulse}]$ \\
\cline { 2 - 3 } & Encoder pulse & $0.03[\mathrm{pulse} / \mathrm{s}]$ \\
\cline { 2 - 3 } & GPS position & $0.1 \sim 0.3[\mathrm{~m}]$ \\
\hline \multirow{2}{*}{$\begin{array}{c}\text { Sampling } \\
\text { period }\end{array}$} & GPS attitude & $20 \sim 40[\mathrm{deg}]$ \\
\cline { 2 - 3 } & Odometory $\tau$ & $0.01[\mathrm{~s}]$ \\
\cline { 2 - 3 } & GPS position & $0.05[\mathrm{~s}]$ \\
\cline { 2 - 3 } & GPS attitude & $0.05[\mathrm{~s}]$ \\
\hline
\end{tabular}

ユニットの情報と自ユニットの情報を式(17)，(18)を用いて 推定值を計算することで，C法に基づきセンサユニット間 の情報統合を行う．ただし，本研究では式(17)，(18)におけ る重み係数を粗密探索により最適解を求めた.

式(17)，(18)からも分かるように，Ｃ法では任意の数の情 報を統合可能なため, PnP 型位置推定法では任意の数のセ ンサユニットを接続した場合においても柔軟に情報統合を 行うことが可能となっている.

\section{4. 実験}

本章では，2章で述べた中央集中型自己位置推定手法と， 本論文で提案した PnP 型自己位置推定手法を比較すること でその有効性を確認する. 本実験で用いた移動口ボット・搭 載センサのパラメータを表 1 に示す。 なお, 本実験は上空 が開けており GPSが比䡈的精度よく観測可能な著者らの大 学構内の広 駐車場構内で行った. また GPS 位置言十測值お よひ姿勢計測值の標準偏差は，GPS 受信機加ら得られる計 測精度情報を用いる。

本夷験では，移動口ボットから得られるオドメトリ情報 およびGPSから観測される位置情報・姿勢角情報を, それ ぞれEthernetを介してUDPマルチキャスト通信で送信する. そして GPS 位置ユニット，GPS 姿勢ユニットは，UDP マ ルチキャスト通信により Ethemet から送信された対応する 情報を取得し，各ニニットで推定した情報をUDP マルチキ ヤスト通信で送出することで, 本論文で提案した PnP 型シ ステムを実装した.

図6(a)は移動ロボットを 8 の字状に走行させた時の PnP 型位置推定システムの位置推定結果と RTK-GPS 位置観測 值を示したものであり，図 6(b)は図 6(a)の(A)点付近および (B)点付近を拡大したものである. 図 6(b)からら，PnP 型位置 推定システムの位置推定結果が RTK-GPS 位置観測值より も移動ロボットの進行方向に対して常に右側に存在してい る.これはGPSアンテナがロボット中心に対して左側にず れて設置されているためであり，PnP 型位置推定システム が正しい位置推定を行っていることが定性的に確認できる. 
戝7はGPSアンテナ取り付け位置(センサパラメータ)を, (a)従来型の中央集中型位置推定システムおよび(b) PnP 型位 置推定システムにより推定した結果である. これらの結果 より, PnP 型位置推定システムを用いた場合，中央集中型 と比較すると推定精度が1〜2割程度少化していることが分 かる. 一方で, 表 1 よりそもそも GPS 位置計測值の標淮㴜 差が 10〜 30cm 程度であったことを勘案すれば, PnP型位置 推定システムによる推定結果も十分に実用的なレベルであ ると考えることができる. また PnP 型自己位置推定の処理 時間は，Intel Pentium $41.6 \mathrm{GHz}$ のPCを用いた場合 1[ms]以 下であり，中央集中型と比べてもほとんど処理コストの增 加が見られなかった。

これらのことから，提案したPnP 型位置推定手法は，従 来型の中央集中型位置推定手法に対して若干の精度劣化が 生じるものの，実用的なレベルで位置姿勢倠定が可能であ ることが確認できた。

\section{5. 結言}

本論文では, ユーザによる柔軟なセンサの選択・ 自由なセンサ設置を可能とする Plug and Play(PnP) 型自己位置推定手法を提案し, 従来手法との比較 によりその有効性を確認した，本論文の提案事項 は下記の通りまとめられる。

・ 各センサを, 演算器を有するセンサユニットとし て取り扱い，分散型の情報統合手法に基づき情 報統合を行うことで, センサの種類·数に依存 せず自己位置推定を行うことが可能である.

・センサ設置位置を自動推定可能なため, エーザ によるセンサの自由な設置が可能である.

・従来手法である中央集中型の自己位置推定手 法と比較すると若干の精度劣化が見られるも のの，使用するセンサの精度と比較し十分に高 い精度で自己位置を推定することが可能であ る。

\section{謝辞}

本研究の一部は, 科学研究費補助金( 若手研究 (B) 20700155)によって行われた研究である. 記し て謝意を示す.

\section{文献}

(1) Tsumaki,T., Robots for Dangerous Operation, Journal of the Robotics Society of Japan, Vol.18, No.7 (2000), pp.946-950.

(2) Tajima,S., Aoyama,H., Seki,T., Ishikawa,K., Yokota,K., Ozaki,K., and Yamamoto,S., Development of Robotic Floor Cleaning System for High-Rise Buildings, Journal of the Robotics Society of Japan, Vol.22, No.5 (2004), pp.595-602.

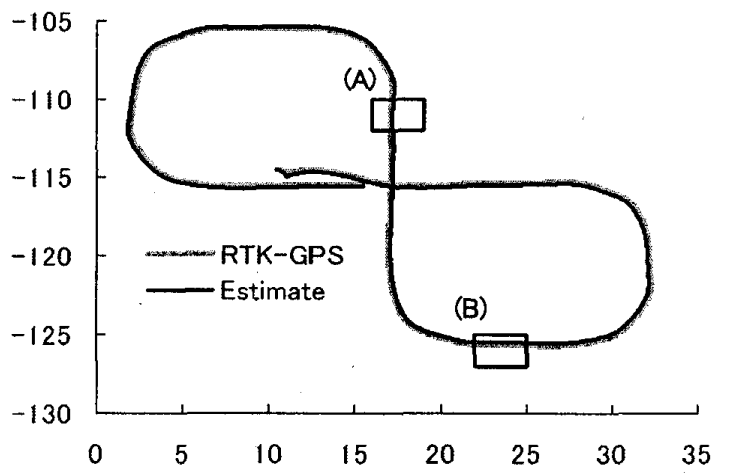

(a) Trajectory of PnP estimator and RTK-GPS

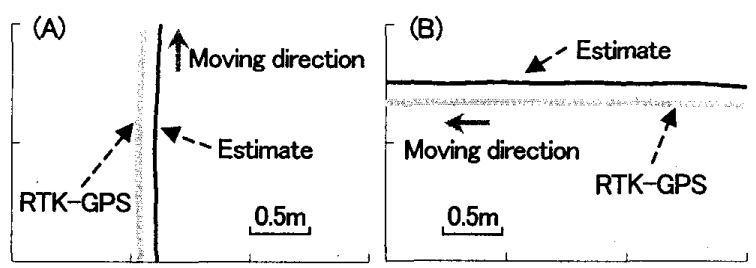

(b) Enlarged trajectory

Fig.6 Position estimate by PnP estimator

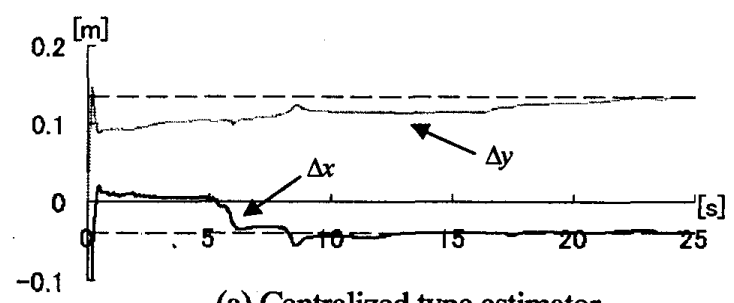

(a) Centralized type estimator

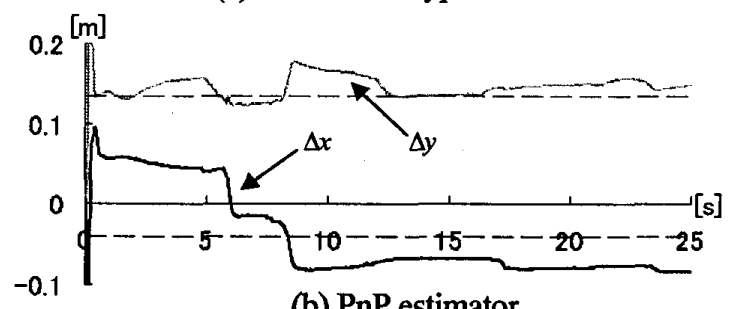

(b) PnP estimator

Fig.7 Comparison of sensor parameter estimate

(3) Mori,H., Intelligent Wheelchair toward Practical Use, Journal of the Robotics Society of Japan, Vol.22, No.7 (2004), pp.856-859.

(4) Omae,M., Fujioka,T., Differential GPS-Based Position Measurement and Steering Control for Automatic Driving, Transactions of the Japan Society of Mechanical Engineers, Series C, Vol. 65, No.634 (1999), pp.2371-2378.

(5) Moon,I., Miura,J., and Shirai,Y., Online Viewpoint and Motion Planning Method under Uncertainty, Journal of the Robotics Society of Japan, Vol.17, No.8 (1999), pp.1107-1113.

(6) Hashimoto,M., Ishida,Y., and Oba,F., 3D Dead Reckoning for Modular Vehicle Based on Decentralized Data Association, Transactions of the Japan Society of Mechanical Engineers, Series C, Vol. 69, No.677 (2003), pp.164-171.

(7) Julier,S.J., and Uhlmann,J.K., A Non divergent Estimation Algorithm in the Presence of Unknown Correlations, Proceedings of the American Control Conference, Vol.4 (1997), pp.2369-2373. 